911.375.62:656:550.4(477.83)

\author{
• олошин, . ик йло \\ ввівський н ціон льний університет імені в н \\ вул. . орошенк , 41, м. ввів, 79000, кр їн
}

исвітлено природні особливості з хідної ч стини об бічних 150 м смуг втотр си ьвівр ковець (46 км) т зроблено еколого-геохімічну оцінку грунтового покриву. осліджено поширення тектонічних структур, скл д третинних (піски, пісковики, в пняки, мергелі), четвертинних піщ но-супіщ них (водно-льодовикових) і лесових суглинистих відкл дів. здовж тр си cх р ктеризов но гідрогр фічну мережу, рослинний покрив лучних і лісових угідь, вл стивості основних різновидів грунтів території, через яку буде прокл ден тр с . ет льно досліджено еколого-геохімічний режим грунтів при втом гістр льних смуг. изн чено один дцять техногенних полют нтів і розр хов но коефіцієнт кумуляції н різній відст ні від н явної і з проектов ної дороги.

лючові слов : геохімічний н ліз, л ндш фтн структур , об бічні смуги, інгр дієнтний скл д, місцевий кл рк.

еохімічні особливості грунтів при втом гістр льних смуг вивч ло б г то н уковців. ослідники з'ясув ли, що в грунт х при втом гістр льних смуг відбув ється інтенсивне н копичення техногенних полют нів, у тому числі плюмбуму з вихлопних г зів втомобілів. озсіюв ння об біч м гістр лі з лежить від гіпсометричного рівня місцевості й може сяг ти до 600 м від полотн дороги. сновн ч стин цього полют нт перев жно кумулюється в 100 м придорожній смузі [1]. н ш погляд, кту льною є оцінк і моделюв ння екологічної ситу ції в меж х 3 проектов ної олімпійської втом гістр лі ьвів- р ковець т суміжної з нею території.

хідн ч стин олімпійської втом гістр лі бере поч ток від укр їнсько-польського відтинку держ вного кордону кр їни (селищ міського типу р ковець) і простяг ється до сел еликополе, її довжин - 46 км. г льн довжин тр си до кінцевого пункту призн чення ст новить близько 84,6 км. втом гістр ль проходитиме північніше с. p'янці, через с. ередвір'я, північніше сіл оснівки, линівки, ерчик , рилбичів, між існович ми і олошкович ми, мельною, токою і оброст н ми, де перетин тиме з лізничну колію.с.м'яноброди проходитиме через нині діючу втомобільну тр су в н прямі н ородок. 46-му кілометрі проходитиме південніше с. еликополе.

лощ вилучених під проект будівництв земель ст новить 631,1 г, у тому числі ріллі - 261,8 г , прис дибних земель - 87 г , п совищ - 129 г, лісу - 51,7 г , іншого призн чення - 101,6 г . рім того, 32,2 г площі з йнято суч сною втодорогою.

ектонічно територія втом гістр лі розміщен в меж х молодої хідноєвропейської (епіп леозойської) пл тформи зі структурними елемент ми її фунд менту:

(C) олошин ., ик йло ., 2011 
озтоцьким т уж йським м сив ми зон б йк льської консолід ції, в - уської т ох нівської зон к ледонської консолід ції [5].

ідповідно до з г льноприйнятого тектонічного р йонув ння, втом гістр ль ьвівр ковець розт шов н в меж х зовнішньої зони ередк рп тського передового прогину н 3 хідному її відрізку т південно-з хідної окр їни д вньої хідноєвропейської (дорифейської) пл тформи н сході. еж між пл тформою т прогином проходить у північно-з хідному н прямі по лінії ідлуби- існевичі- ечич ни, н відрізку втотр си $30-33 \mathrm{kм}$.

вні неогенові породи предст влені міоценовими і міоцен-пліоценовими пісковик ми, піск ми, мергелями, в пняк ми, глин ми [5]. они поширені н відкос х дороги, крутих схил х ярів т б лок. відслоненнях є відкл ди крейди: мергелі, в пняки, клонгломер ти, піски, пісковики.

етвертинні породи досліджув ної ділянки тр си в меж х дсянської моренноз ндрової рівнини предст влені водно-льодовиковими т льодовиковими відкл д ми p нньоплейстоценового зледеніння [5, 6]. долин х рік поширені суч сні люві льні т люві льно-ст ричні н ш рув ння. лювіогляці льні т льодовикові (моренні) відкл ди з гр нулометричним скл дом піщ но-супіщ ні. долин х рік, зниженнях рельєфу сформов ні орг ногенні товщі. болочених територій м йже $18 \%$.

смузі прокл д ння втом гістр лі поширені т кож еолово-делюві льні р нньопізньоплейстоценові леси і лесові суглинки, у місцях виходу н денну поверхню порід верхньої крейди - крейд , мергелі, в пняки, піски, пісковики.

ивчено л ндш фтну структуру з хідної ч стини (46 км) тр си р ковець- оріччя. p c перетин є поліські л ндш фти, які в околицях сел ердихов поступово переходять у л ндш фти озточчя [3].

геоморфологічним р йонув нням тр с проходить через пл топодібні денуд ційні й структурно-денуд ційні рівнини, п смово-хвилясті денуд ційно-еолові (“лесові”) сл бкорозчленов ні рівнини, хвилясті й п смово-хвилясті льодовикові т водно-льодовикові рівнини. хні відкл ди перероблені ерозійними й еоловими процес ми. 3 ході території рівнини сл бкорозчленов ні, перев жно піщ ного гр нулометричного скл ду. ерхів'я р. іжомлі т північн ч стин ородоцького р-ну сильно почленов ні долин ми лесового г бітусу. будовою поверхні 3 хідн ч стин цієї території н лежить до янсько- ністерської моренно-флювіогляці льно- люві льної рівнини, втом гістр ль буде прокл дено через дсянську моренно-з ндрову люві льну рівнину [6].

p с втошляху ьвів- р ковець перетин є річки кло і ноєць (б сейн яну), т кож ерещицю, ом жир, линівку (б сейн ністр ).

iк кло, що протік є у ьвівській обл. т південно-східних воєводств х ольщі, - це пр в приток річки ян (б сейн р. ісли). ї довжин - 76 км. сновні притоки - жомля (лів приток довжиною $43 \mathrm{kM})$, етичин (пр в приток довжиною 40 км). итік р. кло розміщений вище с. кло н висоті 265 м н д рівнем моря. ирин долини колив ється в меж х 0,5-5,0 км. хили долини помірно круті, висотою 30-40 м. пл в з болочен, шириною до 0,8 км. ік $з$ регульов н русловими ст вК ми.

втом гістр ль перетин є p. ноєць у р йоні сіл олошковичі і ердихів. е лів приток р. кло довжиною 63 км від гирл . ирин русл - 0,3-50,0 м, 3 пл ви - 0,11,5 км, долини - 1-3 км. долині ріки розт шов ні відстійники комбін ту “ ірк ”, т кожз крит торфорозробк . 
одний режим річки ноєнець сильно змінений з вдяки впливові лійки депресії, що утворил ся після відк чув ння к р'єрних вод. н слідок цього стік руслом можн спостеріг ти лише під ч с весняної повені чи дощових п водків.

овжин ріки до тр си втошляху - 7,1 км, площ водоз бору - 23,8 км. пл в зернист двостороння, шириною 100-150 м. різ води н д 3 пл вою - 0,5-2,0 м, береги сл бкоз дернов ні, місцями урвисті. ирин русл -1-2 м.

он д $18 \%$ території з йм ють луки. йбільше поширеними тип ми лук є 3 пл вні. уходільні луки з йм ють незн чні площі.

еред $з$ пл вних лук перев ж ють високозл ково-різнотр вні, в тр востої яких $\epsilon$ вівсяниця, тонконіг луговий, серед різнотр в - королиця звич йн , ведмедник, тисячолисник. оширені т кож дрібнозл ково-різнотр вні луки 3 перев ж нням вівсяниці овечої, польовиці білої т звич йної.

схил х п горбів, у місцях вирубув ння лісу т н лісових г лявин х є суходільні луки, перетворені в п совищ . цих лук х перев ж ють білоус, щучник, вівсяниця овеч тощо.

одекуди н межиріччях тр пляються низинні з болочені луки, предст влені різнотр вно-осоковими угрупов ннями з п нув нням осоки просяної, звич йної т жовтої. долин х річок ерещиця т ом жир поширені болот з осоковим, осоково-гіпновим тр вост ном т покл д ми торфу (біля сіл льчиці т оріччя). евеликі болот $\epsilon$ т кож у к рстових з п дин х н вододільних поверхностях.

сі луки досліджув ної території потребують комплексу культуртехнічних з ходів, н деяких площ $\mathrm{x}$ - корінної меліор ції через низьку якість т продуктивність.

уч сний лісовий покрив території є вторинним, це 3 лишки б г тої в минулому рослинності, зн чно зміненої діяльністю людини. сновний тип природної рослинності - ліси, що покрив ють приблизно $30 \%$ площі, у минулому площ покриття бул зн чно більшою.

ліс х перев ж ють широколистяні види - гр б, дуб, бук з домішк ми клен , явоp , липи т ін. p пляються т кож хвойні: сосн , смерек, ялиця. тучні лісові н с дження предст влені перев жно сосною.

ьогодні букові, буково-дубово-гр бові ліси є лише н п горб х лесових місцевостей, буково-соснові т дубово-соснові ліси приурочені до піщ них місцевостей озточчя. лоскі т злегк хвилясті рівнини пілля пр ктично безлісі, хоч подекуди з лишились невеликі дубово-гр бові г ї.

ромислового зн чення місцеві ліси не м ють, вони відігр ють водоз хисну роль т ч стково н леж ть до зеленої зони міст ьвов . стин лісових м сивів $є$ у скл ді л ндш фтних 3 к зників місцевого зн чення т є об'єктом природно-з повідного фонду ьвівщини.

йбільше поширені грунти при втом гістр льних смуг з хідної ч стини втом гістр лі - дерново-, сл бко- і середньопідзолисті оглеєні грунти н водно-льодовикових відкл д х піщ ного і глинисто-піщ ного гр нулометричного скл ду. ерново-прихов нопідзолисті глеюв ті, дернові оглеєні піщ ні грунти сформув лись н водно-льодовикових т делюві льних суглинк х, див. рисунок.

погр ниччі з озточчям фр гмент ми поширені грунти, що сформув лись н лесових пород х: темно-сірі, ясно-сірі т сірі лісові глеюв ті грунти в поєдн нні з грунт ми різного ступеня змитості. розчленов них ділянк х рельєфу сл бко змиті грунти ст новлять $13,5 \%$, середньо змиті - 7,2 \%, сильно змиті $-1,7 \%$. іля с. ердихов , де почин ється пілля, перев жно поширені ясно-сірі й темно-сірі опідзолені грунти різ- 
ного ступеня оглеєння т змитості. них сл бко змиті грунти з йм ють площу 13$18 \%$, середньо змиті - 4-3, сильно змиті - 2-3\%.

зниженнях рельєфу, низьких тер с х рік т приозерних ділянк х перев ж ють гігроморфні грунти: дернові, дерново-глейові, лучні, лучно-болотні, торфово-болотні грунти т торфовищ низинні.

осліджено геохімічні особливості грунтів, через які проходитиме з проектов н втом гістр ль. фондовими м тері л ми ерж вного н укового центру р діогеохімії н вколишнього середовищ про н лізов но концентр цію хімічних елементів у грун$\mathrm{T}$ x техногенного походження. об бічних 150 м смуг х опис но геохімічні вл стивості грунтів 25 екополігонів т визн чено т кі хімічні елементи: сполуки $\mathrm{Hg}, \mathrm{Pb}, \mathrm{Cd}$, $\mathrm{Zn}, \mathrm{Co}, \mathrm{Cu}, \mathrm{Ni}, \mathrm{Mn}, \mathrm{Cl}^{-}, \mathrm{S}_{4}^{2-}$ і вміст н фтопродуктів. 'ясов но, що кількість ртуті в грунті ст новить 0,03-0,07 мг/кг і перевищує кл ркове зн чення н 0,02-0,06 мг/Кг [2]. ількість а змінюється від 3,71 до 4,4 мг/кг. ого вміст перевищує кл ркове зн чення в 7,4, - в 1,23 р з . міст Рb невисокий і змінюється в інтерв лі 1,25-5,0 мг/кг. е пов'яз но з інтенсивним промивним режимом грунтів піщ но-супіщ ного гр нулометричного скл ду. міст інших хімічних елементів техногенного походження т кий, мг/кг грунту: $\mathrm{Zn}-0,9-38,5, \mathrm{Co}-1,25-3,75, \mathrm{Cu}-1,33-6,0, \mathrm{Ni}-1,33-3,33, \mathrm{Mn}-1,35-$ $12,16, \mathrm{Cl}-1,19-1,57$, н фтопродуктів - 0,01-0,34. міст зг д них хімічних елементів у грунт х не перевищує гр ничнодопустимих концентр цій, що пояснюють, по-перше, легким гр нулометричним скл дом грунтів; по-друге, прокл д нням втом гістр лі через умовно чисті території. зн чимо про ще одну особливість грунтів, с ме - дуже високий вміст $\mathrm{SO}_{2}-1580$ мг/кг (1,6 г/кг). окремих зр зК х ді п зон ст новить 1,66262,3 мг/кг, що є н слідком видобутку т розсіюв ння сірки н ворівщині.

т блиці н ведено розр хунки коефіцієнт кумуляції хімічних елементів техногенного походження в грунт х придорожніх смуг. сі хімічні елементи виявлені в грунт х у меж х 150 м смуги об біч проектної втом гістр лі, згрупов ні у кл си в жких мет лів 3 токсичністю: перший кл с охоплює $\mathrm{Hg}, \mathrm{Pb}, \mathrm{Cd}$ i $\mathrm{Zn}$, другий - $\mathrm{Co}, \mathrm{Cu}, \mathrm{Ni}, \mathrm{Cl}$; третій - Mn, $\mathrm{SO}_{4}$; четвертий - н фтопродукти. фонову величину прийнято середній пок зник з мінім льних зн чень для кожного хімічного елемент зокрем .

озглянемо просторовий розподіл хімічних елементів у грунт х придорожніх смуг втом гістр лі з огляду н їхні коефіцієнти кумуляції. люмбум, який н лежить до першого кл су небезпеки з токсичністю, у придорожніх грунт х розподілений нерівномірно, що підтверджують коефіцієнти кумуляції. они перевищують кл ркове зн чення 4 мг/кг в 1,25 р 3 . прикл д, біля с. ульове (5 км від тр си, лучн рослинн соці ція) вміст плюмбуму перевищує середнє кл ркове зн чення в 47 р зів; біля c. оброст ни перевищує фоновий кл рк у 38 р зів; у грунт х з пл ви р. кло вміст $\mathrm{Pb}$ перевищує фоновий пок зник у 30 р зів. при втом гістр льних грунт х під сосновим лісом вміст Рb вищий від фонового в 85 р зів. іля грунтової дороги (рілля) вміст $\mathrm{Pb}$ вищий від ет лонного пок зник тільки в 2 р зи, що пов'яз но з посиленим геохімічним обігом.

голосимо, що дуже високий вміст $\mathrm{Pb}$ в грунт $\mathrm{x}$ при втом гістр льних смуг н окремих ділянк х зумовлений н йвищим н в нт женням втомобільного тр нспорту. рунти долинних ділянок (тер сових комплексів) т кож відрізняються високим н копиченням втомобільного $\mathrm{Pb}$.

о першого кл су з токсичністю т кож н леж ть Cd i Zn. г льн 3 кономірність н копичення в грунт х придорожніх смуг т долин х рік цих техногенних полют нтів 
поляг є в т кому: у місцях н йбільшого н в нт ження втомобільним тр нспортом т іншими джерел ми з бруднення вони н $б$ г то перевищують місцеві фонові зн чення.

оефіцієнти кумуляції хімічних елементів у грунт х при втом гістр льних територій ьвів- р ковець

\begin{tabular}{|c|c|c|c|c|c|c|c|c|c|c|c|}
\hline \multirow{4}{*}{$\begin{array}{c}\text { ідст нь (в } \\
\text { км) від } \\
\text { нульової } \\
\text { точки } \\
\text { ( р ківця), } \\
\text { грунтовий } \\
\text { індекс }\end{array}$} & \multicolumn{11}{|c|}{$\begin{array}{l}\text { еревищення хімічних елементів н д середніми мінім льними величин ми, } \\
\text { мг/кг* }\end{array}$} \\
\hline & \multicolumn{11}{|c|}{ кл си токсичності } \\
\hline & \multicolumn{4}{|c|}{ I } & \multicolumn{4}{|c|}{ II } & \multicolumn{2}{|c|}{ III } & IV \\
\hline & $\mathrm{Hg}$ & $\mathrm{Pb}$ & $\mathrm{Cd}$ & $\mathrm{Zn}$ & Co & $\mathrm{Cu}$ & $\mathrm{Ni}$ & $\mathrm{Cl}^{-}$ & Mn & $\mathrm{SO}_{4}$ & $\begin{array}{l}\phi- \\
\text { топр. }\end{array}$ \\
\hline $\begin{array}{l}0,5 \text { км, лук } \\
\text { слп і сп }\end{array}$ & $<0,03$ & 1,25 & 0,86 & 38,5 & 3,5 & 2,6 & 2 & 1,57 & 1,78 & 0,6 & 0,02 \\
\hline $\begin{array}{l}3,5 \text { км, рілля, } \\
\text { л }\end{array}$ & & 2 & 2,71 & 2 & 0,75 & 1,33 & 1,33 & 1,57 & 5,14 & 11,3 & 0,03 \\
\hline $\begin{array}{l}\text { 6,5 км, лук , } \\
\text { слп } \mathrm{gl}\end{array}$ & & MK & 1,85 & 1,09 & 2,75 & 2 & 2,66 & 1,57 & 1,78 & 262,3 & \\
\hline $\begin{array}{l}9,5 \text { км, лук , } \\
\text { н }\end{array}$ & & 0,75 & 0,85 & 0,9 & 3,75 & 2 & 1,33 & 1,47 & 2,32 & 250 & \\
\hline $\begin{array}{ll}11,5 \mathrm{kм}, & \\
3 \text { пл в }, \quad \text { пा } \mathrm{gl}\end{array}$ & & 1,75 & 0 & 1,27 & 0,75 & 1,33 & 0,66 & 1,57 & $<20$ & 11,66 & \\
\hline $\begin{array}{c}14,5 \text { км, рілля, } \\
\text { пा }\end{array}$ & & 2 & 1,42 & 1,64 & 3,25 & 1,33 & 1,33 & 1,19 & 6,54 & 0,6 & \\
\hline $\begin{array}{l}17 \text { км, } \\
\text { сосновий ліс, } \\
\text { пп }\end{array}$ & 0,07 & 5 & 1,14 & 1,81 & 0,75 & 2 & 1,33 & 1,57 & 2,32 & 6 & $<0,01$ \\
\hline 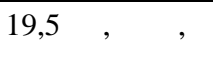 & & 0,75 & 1,28 & 0,9 & 2,75 & 1,33 & 1,33 & 1,52 & 0,65 & 1,66 & \\
\hline$\underset{\text { слп }}{21,5 \text { км, лук , }}$ & $<0,04$ & 0,75 & 1,14 & 0,9 & 3,25 & 0,6 & 0,26 & 0 & 1,35 & 1580 & \\
\hline $\begin{array}{l}23 \text { км, лук , } \\
1^{\text {оп } \mathrm{gl}}\end{array}$ & & 2,75 & 3,14 & 2 & 2,75 & 2 & 2 & 1,28 & 12,16 & 0,6 & \\
\hline $\begin{array}{l}31 \mathrm{kм}, \text { рілля, } \\
2^{\mathrm{o \Pi}} \mathrm{gl}\end{array}$ & 0,03 & 1,25 & 0,4 & 1,8 & 1,25 & 2 & 2 & 1,57 & 4,29 & 0,6 & $<0,01$ \\
\hline $\begin{array}{l}38,5 \mathrm{Kм}, \text { рілля, } \\
3^{\text {oп } \mathrm{gl}}\end{array}$ & 0,03 & 2,25 & 3,71 & 2,54 & MK & 6 & 3,33 & 1,47 & 7,1 & 1,33 & $<0,01$ \\
\hline MK & - & 4 & 0,07 & 5,5 & 0,4 & 1,5 & 1,5 & 21 & 37 & 3 & - \\
\hline
\end{tabular}

* цінк екологічного ст ну викон н 3 м тері л ми ерж вного н укового центру р діогеохімії н вколишнього середовищ, ст ном н 2001p.

римітки: мк - місцевий кл рк; л - болотні грунти; $\quad$ слп - дерново-сл бкопідзолисті грунти; ${ }^{\text {сп }}$ - дерново середньопідзолисті грунти; пा - дерново-прихов нопідзолисті грунти; пп gl - дерново-прихов нопідзолисті глеюв ті грунти; п - дерново-підзолисті грунти; слп $\mathrm{gl}$ - дерново-сл бкопідзолисті глеюв ті грунти;

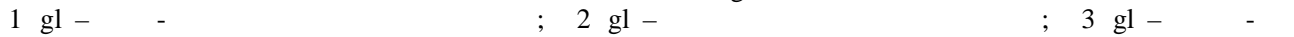
опідзолені оглеєні грунти; н - торфовищ низинні.

прикл д, н першому полігоні перевищення вмісту $\mathrm{Cd}$ i $\mathrm{Zn} \mathrm{н} \mathrm{д} \mathrm{фоновими}$ пок зник ми, відповідно, дорівнюють 14,6 і 21,6; н другому - 19,4 і 30,9; н 12-му 63,1 і 43,7 p 3 . цих же дослідних ділянк х перевищення вмісту $\mathrm{Zn}$ порівняно з фоновими змінюється від 15,5-43,3 р 3 . 


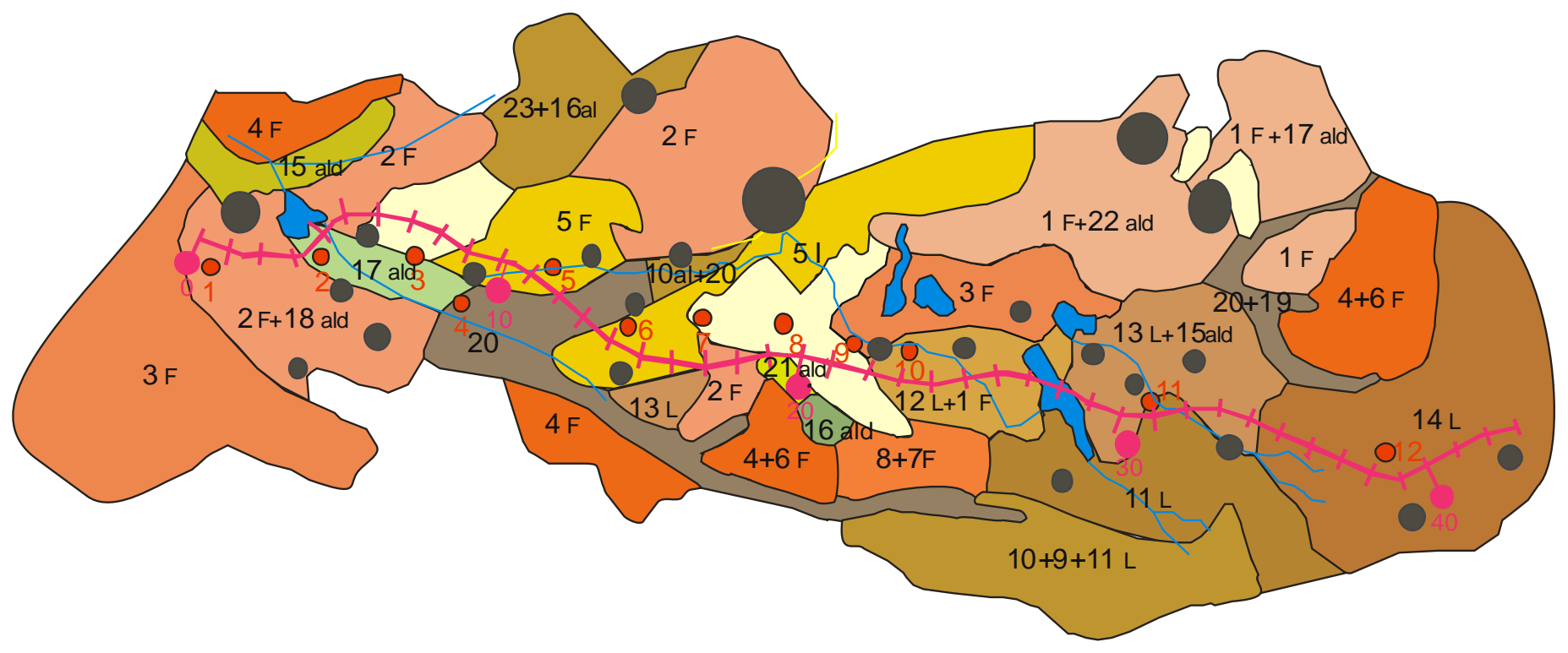

сшт 6 1: 200000

рто-схем грунтового покриву при втом гістр льних смуг з хідної ч стини тр си р ковець- ьвів. 
ерново-підзолисті грунти н д вньо люві льних, водно-льодовикових відкл д х ерново-прихов нопідзолисті піщ ні і глинисто-піщ ні грунти (борові піски) ерново-сл бко- і середньо підзолисті піщ ні т глинисто- піщ ні грунти ерново-сл бкопідзолисті супіщ ні і суглинкові грунти ерново-середньопідзолисті супіщ ні і суглинкові грунти

ерново-підзолисті оглесні грунти н д вньо люві льних, водно-льодовикових відкл д т делюві льних суглинк $\mathbf{x}$

5 ерново-прихов но підзолисті і сл бкопідзолисті глеюв ті т глинисто-піщ ні грунти

6 ерново-середньо- і сильнопідзолисті глеюв ті супіщ ні і суглинкові грунти

7 ерново- середньо- і сильно підзолисті глейові супіщ ні суглинкові грунти

ідзолисто-дернові оглеєні грунти

$$
\text { ідзолисто-дернові грунти }
$$

9 сно-сірі опідзолені грунти

10 ірі опідзолені грунти

11 емно-сірі опідзолені грунти

підзолені оглеєні грунти перев жно н лесових пород $\mathbf{x}$

12 сно-сірі опідзолені оглеєні грунти

13 ірі опідзолені оглеєні грунти

14 емно-сірі опідзолені оглеєні грунти

15 учні грунти

учні грунти н делюві льних т люві льних відкл д

учно-болотні грунти н люві льних т делюві льних відкл д

учно-болотні грунти

олотні і торфово-болотні грунти н різних пород $\mathbf{x}$

17 олотні грунти

18 орфув то-болотні грунти

19 орфово-болотні грунти

20 орфовищ низинні

орфовищ

ернові, піщ ні т глинисто-піщ ні грунти

орфов ищ

22 ерново-оглеєні піщ ні і глинисто-піщ ні грунти

23 ернові оглеєні супіщ ні і суглинкові грунти

рунтоутворюв льні т підстильні породи

L еси і лесові породи

$\mathrm{F}$ одно-льодовикові відкл ди

ald лювій-делювій

sep

проектов н втом гістр ль

ьвів- $\mathrm{p}$ ковець

$\frac{0}{1 \ldots}$

селені пункти

очки відбору проб грунту 
імічні елементи другого т третього кл су токсичності ( o, $\mathrm{Cu}, \mathrm{Ni}, \mathrm{Cl}$ ) розприділені у при втом гістр льних грунт х нерівномірно. йвищі пок зники з фіксов ні в річкових долин х і знижених ділянк х рельєфу. изькі пок зники кумуляції з фіксов ні н орних землях, підвищених н дз пл вних тр с х. кі особливості, без сумніву, пов'яз ні з поверхневим т геохімічним перерозподілом полют нтів з підвищених форм рельєфу у знижені. рім того, в жливу роль у перерозподілі техногенних полют нтів відігр ють водні потоки. голосимо, що м ксим льній кумуляції хімічних елементів сприяють дорожні н в нт ження у місцях скупчення втотр нспорту. скільки ріки розмив ють крейдові т третинні відкл ди, скл дені в пняк ми, піск ми, глин ми, лесовими пород ми, то зн чн ч стин високих пок зників н копичення хімічних елементів може бути пов'яз н з різнотипністю грунтів і гірських порід.

ксим льні зн чення $\mathrm{Co}, \mathrm{Cu}, \mathrm{Ni}$, що вир жені в коефіцієнт х кумуляції, перевищують фонові: Со в 46,8-59,5 р з , $\mathrm{Cu}-44-102, \mathrm{Ni}-34-56$ р зів. грунт х решти екологічних полігонів перевищення колив ється в меж х 2-10 p зів. уже високі пок зники коефіцієнтів кумуляції з фіксов ні для III групи хімічних елементів і сполук: $\mathrm{Mg}$ перевищує кл рковий пок зник у 39-206,7 р $3, \mathrm{SO}_{4}^{2-}-200$ і пон д 2 тис. р зів, що пов'яз но з розсіюв ннями цієї хімічної сполуки від добув ння сірки т іншими джерел ми з бруднення в зоні будівництв м гістр льної тр си. фтопродукти (четвертий кл с токсичності) т рсен (перший кл с токсичності) в грунт х при втом гістр льних смуг тр пляються фр гмент рно і м ють низькі пок зники кумуляції.

скільки тр с буде прокл ден через територію з мінім льним техногенним впливом (відсутність промислових комплексів), проходитиме н зн чній відст ні від суч сної втомобільної дороги т в місці поширення грунтів піщ но-супіщ ного гр нулометричного скл ду з високим коефіцієнтом фільтр ції, то інтенсивного н копичення техногенних полют нтів у меж х іiі розт шув ння не прогнозують, з винятком оксиду сірки, що м є ер ційне поширення і зумовлене розробкою родовищ сірки н ворівщині.

дн к використ ння ет лонних цифрових зн чень для кожного хімічного елемент , що визн чені в грунт х при втом гістр льних смуг, т розр хунки коефіцієнтів кумуляції підтвердили н явність тенденції до н копичення техногенних полют нтів від місцевих і тр нскордонних джерел.

1. олошин . . собливості геохімічного з бруднення при втом гістр льних смуг олині / . . олошин, . . твійчук, . . епкий. уцьк : “ерен”, 2009. 244 с.

2. $\quad$ пn чевский . . рогнозиров ние процессов з грязнения почв (и биосферы) / . . рп чевский // есн. оск. ун-т . ер. 17. очвоведение. 1993. № 2. . 63-69.

3. ов льчук . еоекологія озточчя / . ов льчук, . етровськ // ьвів : ім. в н р нк . ьвів, 2003. 192 с.

4. ец, . . н ндш фтн к рт ьвівської обл сті м сшт бу 1:200000 / . . ец л // існ. ьвів. ун-ту. ер. геогр. 2003. ип. $29 . \quad$. 1. . . 58-65.

5. удько .. еологія з основ ми геоморфології / . . удько, . . д менко, . . епіжко, . . оч н // ернівці : ид. дім “ укрск”, 2010.398 с.

6. ись . еоморфологія / . . ись // ьвів : ид-во ьвів. ун-ту, 1962. . 162-222. 


\section{GEOCHEMICAL SOIL ANALYSIS OF THE STRIPS OF LAND ON BOTH SIDES OF THE LVIV-KRAKOVETS' HIGHWAY}

\section{Voloshyn, Yu. Chykailo}

Ivan Franko National University of Lviv,

. Doroshenko St., 41, UA - 79000 Lviv, Ukraine

In this article the natural peculiarities of the stripes on both sides of the Lviv-Krakovets Olympic highway have been studied. The map of soils has been developed. The geo-chemical features of different soil types have been analysed, deals with natural features of the western part of the highway lanes on both sides of the Lviv -Krakovets $(46 \mathrm{~km})$. The ecological-geochemical assessment of soil roadside hunks width of $150 \mathrm{~m}$, investigation of distribution of tectonic structures, tertiary structure (sand, sandstone, limestone, marl), quaternary sand and sandy (water ice) and loamy loess deposits, along the route described hydrographic network, vegetation cover of meadow and forest lands, properties of the main types of soil area through which the trail will be laid, detail the ecological and geochemical soil profile at main lanes have been analyzed. Determined eleven man-made pollutants and the accumulation ratio was calculated at different distances from existing and projected road.

Key words: geochemical analysis, landscape structure, the stripes on both sides, ingredient composition, local clark.

\section{• олошин, • ик йло}

ьвовский н цион льный университет имени в н

$$
\text { ул. . орошенко, 41, г. ьвов, 79000, кр ин }
$$

ссмотрено природные особенности з п дного уч стк втом гистр ли ьвов- р ковец (46 км) и д но эколого-геохимическую оценку почвенного покров придорожных полос шириной до 150 м. сследов но р спростр нение тектонических структур, сост в третичных (пески, песч ники, известняки, мергели) и четвертичных песч но-супесч ных (водно-ледниковых) и лессовых суглинистых отложений. х р ктеризов но гидрогр фическую сеть тр ссы, p стительный покров луговых и лесных видов угодий. риведено х р ктеристику основных р зновидностей почв территорий, через которые будет проложен тр сс . ет льно ох р ктеризов но эколого-геохимический сост в почв при втом гистр льных полос. пределено одинн дц ть техногенных поллют нтов и р ссчит но коэффициент ккумуляции н $\mathrm{p}$ зном р сстоянии от существующей и проектируемой дороги.

лючевые слов : геохимический н лиз, л ндш фтн я структур, при втом гистр льные полосы, ингредиентный сост в, местный кл рк.

т ття н дійшл до редколегії 17.09.2010 рийнят до друку 16.11.2010 